\title{
Benthic studies of the northwest African upwelling region: psychrophilic and psychrotrophic bacterial communities from areas with different upwelling intensities*
}

\author{
Hans-Jürgen Rüger \\ Alfred-Wegener-Institut für Polar- und Meeresforschung, D-2850 Bremerhaven, Federal Republic of Germany
}

\begin{abstract}
Distinct bacterial communities were found in the sediments of the northwest African upwelling area at 17 and $21^{\circ} \mathrm{N}$ compared to an area with low upwelling intensities at 29 and $35^{\circ} \mathrm{N}$. The bacterial community of the central upwelling area at $17 / 21^{\circ} \mathrm{N}$ consisted of approximately equal proportions of Gram-negative strains belonging mainly to the genera Alteromonas and Vibrio; most of them were psychrophiles. This could be due to the upwelling of cold water masses in this region, where sediment temperatures were on average $2^{\circ} \mathrm{C}$ lower than in the northern part of this upwelling area. Here, Gram-positive psychrotrophic Bacillus strains predominated, tolerating growth temperatures higher than $24^{\circ} \mathrm{C}$. A high proportion of these Bacillus strains fermented various carbohydrates and sugar alcohols and utilized citrate as sole source of carbon and energy. In contrast, the abilities to utilize some glycosides, starch, chitin, fats and proteins, to degrade various $N$-compounds like DNA or arginine, and to reduce nitrates to nitrites were more pronounced in strains from the central upwelling area.
\end{abstract}

\section{INTRODUCTION}

Upwelling causes an enhanced primary productivity rate in water masses of the northwest African continental margin. The centre of this upwelling is found in the Cape Blanc area at $21^{\circ} \mathrm{N}$ throughout the year. Seasonal upwelling occurs south of Cape Blanc to Sierra Leone in winter and spring and to the north up to Morocco in summer (Fütterer 1983).

Studies on benthic activity in upwelling regions are extremely rare, although it is known that primary production of the overlying waters strongly influences benthos standing stock and productivity rate (Thiel 1981). As can be expected, a high biomass has been found in the Cape Blanc area and decreasing values to the north and south of it (Thiel 1982, Pfannkuche et al. 1983, Tan \& Rüger 1989).

Bacteriological investigations of sediments from the northwest African upwelling region are also rare in comparison to explorations in the water column. Cell

\footnotetext{
- Contribution No. 177 of the Alfred-Wegener-Institute for Polar and Marine Research
}

numbers, nutritional properties and taxonomy of planktonic bacteria of the same region have been reported by Meyer-Reil \& Rheinheimer (1973), Bölter \& Meyer-Reil (1974), Tejero (1978), Tejero et al. (1978) and Zimmermann et al. (1980). Quantitative studies have shown a correlation between decreasing cell numbers of benthic bacteria and increasing water depths (Meyer-Reil \& Rheinheimer 1973, Rüger 1975). The distribution and catabolic potentials of different types of sediment bacteria from deep-sea samples of the Cape Blanc area have been investigated by Bensoussan (1979) and Bensoussan et al. (1979). Structures and catabolic potentials of mesophilic bacterial communities at $21^{\circ} \mathrm{N}$ have been reported (Rüger 1985). We found that Agrobacterium-like bacteria predominated in sediments from water depths of 85 to $1023 \mathrm{~m}$. In depths greater than $1300 \mathrm{~m}$, however, the populations consisted mostly of carbohydrate-fermenting Bacillus species.

The low deep-sea temperatures, upwelling of cold water masses and existence of psychrophilic bacteria with maximum growth temperatures below $15^{\circ} \mathrm{C}$ (Baross \& Morita 1978, Norkrans \& Stehn 1979, Yay- 
anos \& Dietz 1982) stimulated us to apply an additional incubation temperature of $2{ }^{\circ} \mathrm{C}$ besides $20^{\circ} \mathrm{C}$ during the 60th cruise of RV 'Meteor' in 1982 in the northwest African upwelling region. In contrast to $20^{\circ} \mathrm{C}$, this low incubation temperature yielded increasing numbers of culturable sediment bacteria with increasing water depths (Rüger 1982) and led to the isolation of psychrophilic and psychrotrophic bacteria. Physiology, catabolic potentials and taxonomy of these low-temperature-adapted bacterial communities from the Cape Blanc and adjacent areas are described here and compared with mesophilic bacterial strains isolated during a previous cruise of RV 'Meteor' in 1975.

\section{MATERIALS AND METHODS}

Sampling methods and station locations. During the cruise SUBTROPEX in January and February 1982 with RV 'Meteor', sediment samples were taken by means of a box-grab sampler from different water depths at 35 , 29,21 and $17^{\circ} \mathrm{N}$. Station locations, numbers of grabsamplers and methods of subsampling were presented previously (Tan \& Rüger 1989).

Isolation of strains. Viable count determinations at 2 and $20^{\circ} \mathrm{C}$ were carried out with the spread plate method on seawater agar consisting of $1.5 \mathrm{~g}$ peptone, $0.3 \mathrm{~g}$ yeast extract, $0.01 \mathrm{~g} \mathrm{FePO}_{4} \cdot 4 \mathrm{H}_{2} \mathrm{O}, 15.0 \mathrm{~g}$ DIFCO Bacto-agar, $750 \mathrm{ml}$ seawater and $250 \mathrm{ml}$ distilled water. The $\mathrm{pH}$ was adjusted to 7.6. Serial dilutions of the samples were prepared in $75 \%$ seawater. The agar plates and seawater solutions were chilled to $4{ }^{\circ} \mathrm{C}$ before inoculation. Immediately after sediment subsampling the spread plate cultures were prepared. A cold tray was used to ensure that the sample and plate temperatures did not exceed $4^{\circ} \mathrm{C}$ during the inoculation procedure. Four parallel plates were prepared for each incubation temperature and each dilution. The same $2{ }^{\circ} \mathrm{C}$ plates for enumerating culturable bacteria from the top $2 \mathrm{~cm}$ sediment layer were used for isolations of strains at random.

After heating subsamples of the serial dilutions to $80^{\circ} \mathrm{C}$ for $10 \mathrm{~min}$ to inactivate vegetative cells, additional spread plates on spore germination medium II (Rüger 1975) were prepared for enumeration of bacterial spores.

Physiological and biochemical tests. The common identification tests were performed in seawater media as described by Weyland et al. (1970). A modification of the Minitek system was applied for the determination of carbohydrate metabolism (Rüger 1981). Table 1 explaines the abbreviations used in Fig. 3. Tests with psychrotrophic and psychrophilic strains were performed at $12^{\circ} \mathrm{C}$ i extreme psychrophiles were tested at $4^{\circ} \mathrm{C}$. Temperature relationships were determined at 1 , $6,12,18,24,30$ and $37^{\circ} \mathrm{C}$ in seawater broth containing the same concentrations of peptone, yeast extract and $\mathrm{FePO}_{4} \quad 4 \mathrm{H}_{2} \mathrm{O}$ as the seawater agar. Growth was measured at $650 \mathrm{~nm}$ with a Gilford spectrophotometer model 250 after $2,6,10,14$ and $28 \mathrm{~d}$ of incubation.

Table 1. Abbreviations used in Fig. 3

\begin{tabular}{|c|c|c|}
\hline \multicolumn{3}{|c|}{ Monosaccharides } \\
\hline DEX & & Glucose \\
\hline LE & & Fructose \\
\hline AR & : & Arabinose \\
\hline GA & : & Galactose \\
\hline $\mathrm{x}$ & : & Xylose \\
\hline $\mathrm{MA}$ & : & Mannose \\
\hline $\mathrm{R}$ & : & Rhamnose \\
\hline \multicolumn{3}{|c|}{ Di- and Trisaccharides } \\
\hline $\mathrm{TR}$ & & Trehalose \\
\hline $\mathrm{CE}$ & - & Cellobiose \\
\hline M & & Maltose \\
\hline SU & : & Sucrose \\
\hline RA & : & Raffinose \\
\hline ME & : & Melibiose \\
\hline L & & Lactose \\
\hline \multicolumn{3}{|c|}{ Alcohols, Citrate } \\
\hline G & : & Glycerol \\
\hline $\mathrm{MN}$ & : & Mannitol \\
\hline CIT & . & Citrate \\
\hline I & & Inositol \\
\hline SO & : & Sorbitol \\
\hline$A D$ & : & Adonitol \\
\hline DU & & Dulcitol \\
\hline \multicolumn{3}{|c|}{ Glycosides } \\
\hline ES & & Esculin \\
\hline ONPG & & o-nitrophenyl- $\beta$-D-galactoside \\
\hline SA & & Salicin \\
\hline \multicolumn{3}{|c|}{ Polysaccharides } \\
\hline ST & & Starch \\
\hline CHIT & & Chitin \\
\hline$A L G$ & & Alginate \\
\hline \multicolumn{3}{|c|}{ Proteins, Lipase } \\
\hline GEL & : & Gelatin \\
\hline LIP & : & Lipase (Tributyrin) \\
\hline CAS & & Casein \\
\hline \multicolumn{3}{|c|}{$\mathrm{N}$-compounds } \\
\hline DNA & - & DNase \\
\hline ARG & : & Arginine dihydrolase \\
\hline UR & $:$ & Urease \\
\hline LYS & & Lysine decarboxylase \\
\hline ORN & & Ornithine decarboxylase \\
\hline
\end{tabular}

The following terms are used to characterize growth temperatures responses of the strains:

Extremely psychrophilic: Optimum growth temperature between 1 and $6^{\circ} \mathrm{C}$, maximum growth temperature below $12^{\circ} \mathrm{C}$ (in some strains, the optimum temperature was between 6 and $12^{\circ} \mathrm{C}$, then the maximum temperature for growth was betwen 12 and $18^{\circ} \mathrm{C}$ ).

Psychrophilic: Growth at $1{ }^{\circ} \mathrm{C}$, optimum growth 
temperature between 6 and $18^{\circ}$, maximum growth temperature between 18 and $24^{\circ} \mathrm{C}$.

Psychrotrophic: Growth at $1{ }^{\circ} \mathrm{C}$, optimum growth temperature between 12 and $18^{\circ} \mathrm{C}$ (sometimes higher), maximum growth temperature higher than $24^{\circ} \mathrm{C}$.

Mesophilic: No growth at $5{ }^{\circ} \mathrm{C}$, optimum growth temperature between 18 and $30^{\circ} \mathrm{C}$, maximum growth temperature higher than $24^{\circ} \mathrm{C}$.

\section{RESULTS}

\section{Community structures}

The agar plates used for enumeration and isolation of benthic bacteria from areas of different upwelling intensities were incubated at $2{ }^{\circ} \mathrm{C}$. This incubation temperature led to the isolation of bacteria adapted to low temperatures. Grouping the strains according to increasing water depths revealed decreasing numbers of psychrotrophic and increasing numbers of psychrophilic bacteria (Fig, 1a). In general, Gram-positive and psychrotrophic bacterial strains predominated at 35 and $29^{\circ} \mathrm{N}$. The bacterial communities in areas with high upwelling intensities at 21 and $17^{\circ} \mathrm{N}$ consisted of Gram-negative strains with mainly psychrophilic growth characteristics (Fig. 1b).

Most of the Gram-positive strains from $35 / 29^{\circ} \mathrm{N}$. belonged to the genus Bacillus and only a few strains were assigned to the genus Micrococcus or the coryneform group (Fig. 2). The results presented in Table 2 indicate that the greatest part of the Bacillus isolates originated from vegetative cells, because only small numbers of resting spores could be demonstrated in the sediment samples. The Gram-negative isolates belonged to the genera Acinetobacter (2\%), Aeromonas (2\%), Agrobacterium (2\%), Alteromonas (7\%), Pseudomonas (2\%) and Vibrio $(4 \%)$. Because of their small percentages in all 4 transects, the genera Acinetobacter, Aeromonas, Agrobacterium and Pseudomonas were - regardless of their taxonomic relatedness-combined in one column in Fig. 2.

The bacterial communities at $21 / 17^{\circ} \mathrm{N}$ were Gramnegative and consisted of nearly equal proportions of the genera Alteromonas and Vibrio; a minority belonged to Acinetobacter (2\%), Agrobacterium (3\%) and Pseudomonas ( $2 \%)$. The genus Alteromonas was differentiated from Pseudomonas by seawater base requirement for growth, DNase activity, $\mathrm{H}_{2} \mathrm{~S}$-production from cysteine, susceptibility to $10 \mu \mathrm{g}$ chloramphenicol and $50 \mu \mathrm{g}$ furazolidone (Oxoid sensitivity disks), and absence of nitrate reduction to gas and of a constitutive arginine dihydrolase system (Gray \& Stewart 1980, Baumann et al. 1984).

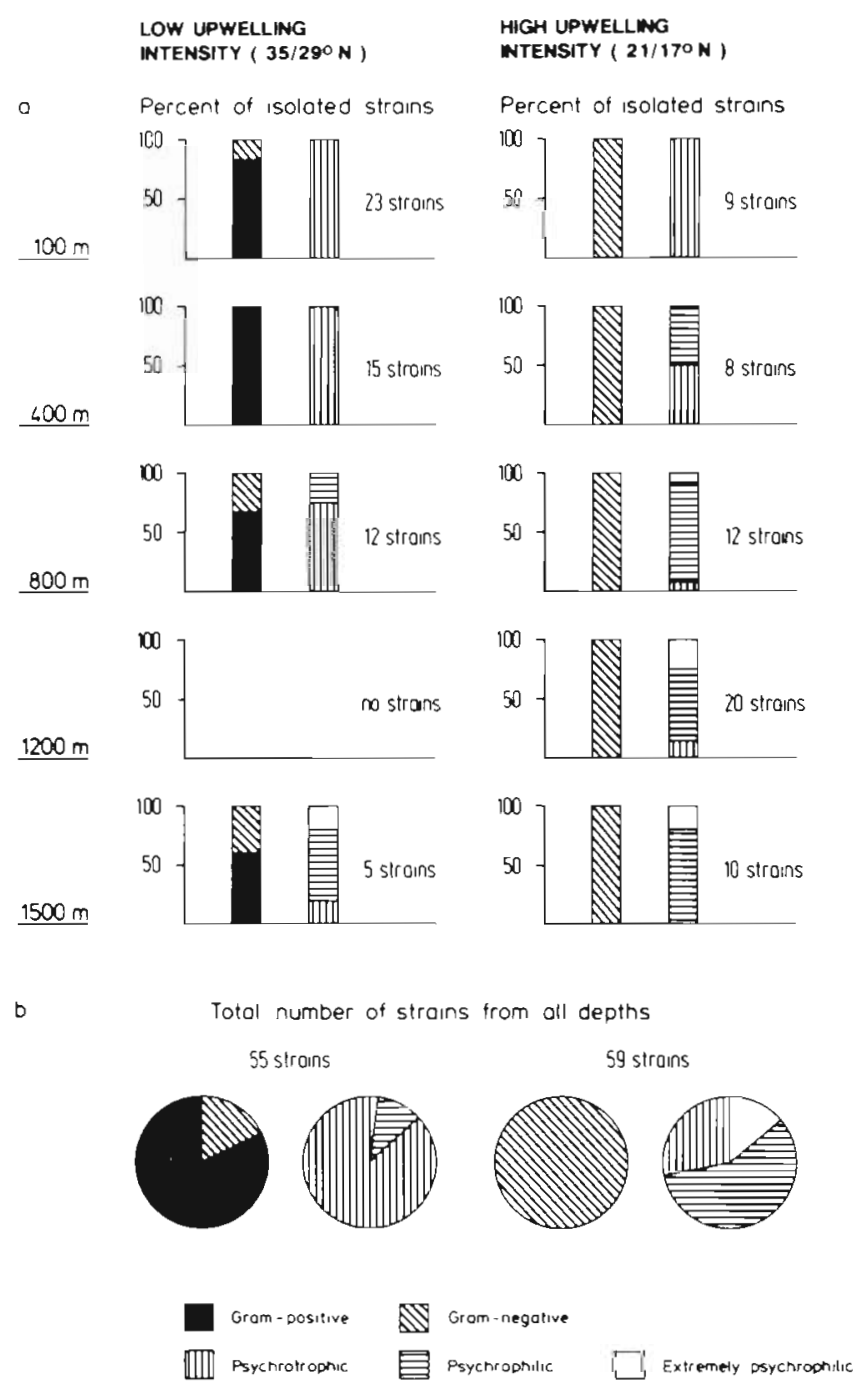

Fig. 1. Gram-reactions and growth temperatures of benthic bacteria from areas of low upwelling intensities $\left(35 / 29^{\circ} \mathrm{N}\right)$ and high upwelling intensities $\left(21 / 17^{\circ} \mathrm{N}\right)$. (a) Gram-reactions and growth temperatures in relation to water depth. (b) Same characteristics for the total number of strains from all depths

\section{Catabolic potentials}

A high proportion of isolates from the area with low upwelling intensity were able to ferment various carbohydrates and sugar alcohols and to utilize citrate as sole source of carbon and energy. In the central upwelling region, however, strains possessing these traits were not abundant. Higher metabolic activities, as expected in upwelling regimes, are represented here by higher proportions of strains able to utilize some glycosides, starch, chitin, fats and proteins, to degrade $\mathrm{N}$-compounds like DNA or arginine and to reduce nitrates to nitrites (Fig. 3). 
LOW UPWELING INTENSITY

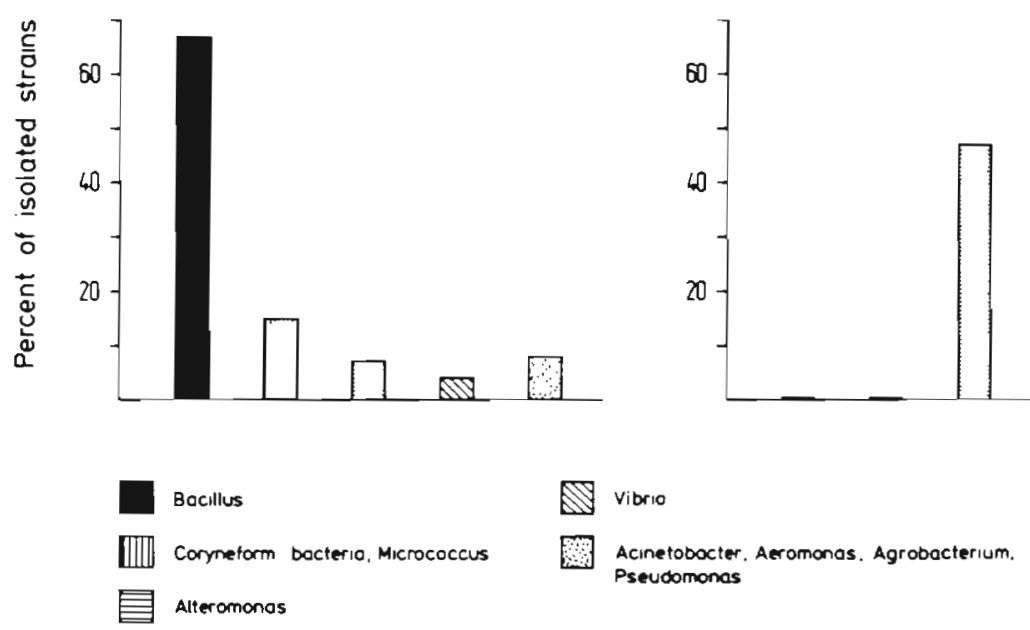

HKG UPWELING INTENSITY

Fig. 2. Taxonomic positions of benthic bacteria from regions with different upwelling intensities

\section{DISCUSSION}

No method of investigation is known to obtain a complete insight into the real world of microbial communities in nature (Kölbel-Boelke et al. 1988). Direct microscopic observations for enumeration and determination of morphologies, or following the fate of nutrients and other chemical compounds in the habitat, do not yield enough information about the organisms involved in the ecological processes. In consequence, isolating the bacteria from their environment and further characterizing them in vitro is still an important method. However, it must be born in mind that all isolation procedures are necessarily selective in quality and quantity and that a great proportion of marine bacteria is not culturable at all (Roszak \& Colwell 1987).
They depend on numerous factors like sample processing, media compositions, temperature and other physical conditions.

The large number of samples needed for an ecological survey results in hundreds of strains to be characterized. Bianchi \& Bianchi (1982) calculated that examining 20 to 30 strains is sufficient to obtain a diversity of bacterial community and that the numbers of tests can be reduced to about 30 without any influence on bacterial diversity. The number of strains which could be isolated during the expedition SUBTROPEX ' 82 was lower than 20 to 30 per sediment sample. The results could therefore not be presented separately for each station or each transect. Therefore, the results of 55 strains from the 2 northern transects were combined and compared to the whole set of

Table 2. Spores and vegetative cells (colony-forming units per $\mathrm{ml}$ of wet sediment, incubation at $2^{\circ} \mathrm{C}$ ) and percentages of $B a c i l l u s$ strains from the total number of isolates presented in Fig. 1. Sed-temp sediment temperature; nd: not determined

\begin{tabular}{|c|c|c|c|c|c|}
\hline Transect & $\begin{array}{l}\text { Depth } \\
(\mathrm{m})\end{array}$ & $\begin{array}{l}\text { Sed.- } \\
\text { temp. }\end{array}$ & $\begin{array}{l}\text { Vegetative } \\
\text { cells }\end{array}$ & $\begin{array}{c}\text { Spores } \\
\text { (\% of vegetative cells) }\end{array}$ & $\begin{array}{c}\text { Bacillus } \\
\text { (\% of isolates) }\end{array}$ \\
\hline $35 \mathrm{~N}$ & $\begin{array}{l}138 \\
423 \\
800\end{array}$ & $\begin{array}{l}16.4 \\
12.6 \\
10.6\end{array}$ & $\begin{array}{r}123.000 \\
93.000 \\
179000\end{array}$ & $\begin{array}{r}\text { nd } \\
20 \\
9\end{array}$ & $\begin{array}{r}52 \\
93 \\
100\end{array}$ \\
\hline $29^{\circ} \mathrm{N}$ & $\begin{array}{r}800 \\
1491\end{array}$ & $\begin{array}{l}1.0 .5 \\
12.0\end{array}$ & $\begin{array}{l}242.000 \\
209.000\end{array}$ & $\begin{array}{l}1 \\
2\end{array}$ & $\begin{array}{l}20 \\
60\end{array}$ \\
\hline $21^{\circ} \mathrm{N}$ & $\begin{array}{r}495 \\
780 \\
1198 \\
1471\end{array}$ & $\begin{array}{r}10.5 \\
8.0 \\
5.9 \\
7.0\end{array}$ & $\begin{array}{r}26.000 \\
142.000 \\
241.000 \\
307.000\end{array}$ & $\begin{array}{l}0.1 \\
0.1 \\
0.4 \\
\text { nd }\end{array}$ & $\begin{array}{l}0 \\
0 \\
0 \\
0\end{array}$ \\
\hline $17^{\circ} \mathrm{N}$ & $\begin{array}{r}84 \\
418 \\
827 \\
1205 \\
1520\end{array}$ & $\begin{array}{r}14.5 \\
10.5 \\
7.0 \\
6.0 \\
8.5\end{array}$ & $\begin{array}{r}16.000 \\
379.000 \\
350.000 \\
356.000 \\
438000\end{array}$ & $\begin{array}{r}0.1 \\
<0.1 \\
<0.1 \\
0.1 \\
<0.1\end{array}$ & $\begin{array}{l}0 \\
0 \\
0 \\
0 \\
0\end{array}$ \\
\hline
\end{tabular}


results of the 59 isolates from the central upwelling area. By this procedure, it was possible to demonstrate significant differences between the bacterial communities of the 2 geographical regions (Figs. 1b, 2 and 3). Combining the results from all water depths in these figures was justified by their great similarity in all depths. An example is shown in Table 3 for 2 depth ranges in the central upwelling area. Exceptions were the growth temperature responses of the strains.

Temperature is one of the most important parameters to be considered in marine microbiology. The incubation temperature of $20^{\circ} \mathrm{C}$, still used for bacterial studies of the deep-sea (e.g. Namsaraev 1985), and originally thought to allow the growth of both psychrophilic and the mesophilic bacteria (Harder \& Veldkamp 1968, Bensoussan et al. 1979), inhibits the growth of autochthonous bacteria having lower maximum growth temperatures. For example, most of the bacteria from deepsea samples of the eastern tropical Atlantic were Grampositive mesophiles when isolated from agar plates incubated at $20^{\circ} \mathrm{C}$. In contrast, the majority of strains from agar plates incubated at ambient temperature of $2{ }^{\circ} \mathrm{C}$ were Gram-negative and extremely psychrophilic (Rüger 1986).

The upwelling of cold water masses is reflected by the sediment temperatures in our area of investigation.
They decreased with increasing depths and were on average $2^{\circ} \mathrm{C}$ lower in the Cape Blanc area than in the 2 northern transects (Table 2). As could be expected, we found higher proportions of psychrophilic and extremely psychrophilic bacteria in the central upwelling area than at $35 / 29^{\circ} \mathrm{N}$; the distribution of psychrophilic bacteria was also dependent on water depth (Fig. 1a, b). The temperature relationships of the strains were tested at $6{ }^{\circ} \mathrm{C}$ intervals. Therefore, the maximum growth temperatures between 18 and $24^{\circ} \mathrm{C}$, used here to define psychrophiles, do not completely meet the definition proposed by Morita, who restricted the temperature growth range of psychrophiles from $0{ }^{\circ} \mathrm{C}$, or less, to $20^{\circ} \mathrm{C}$, or less (Baross \& Morita 1978). The term 'extremely psychrophilic' was used here to characterize those of our bacteria having even lower maximum growth temperatures than the greatest part of the isolates.

Boje \& Tomczak (1978) noted that the high productivity in upwelling regimes seems to be accompanied by a high dominance of a few species (= low diversity). In agreement, we found that the bacterial community in the Cape Blanc area is composed mainly of Alteromonas and Vibrio. On the other hand, with the predominance of Bacillus species, low bacterial diversity was also found at $35 / 29^{\circ} \mathrm{N}$, indicating rather

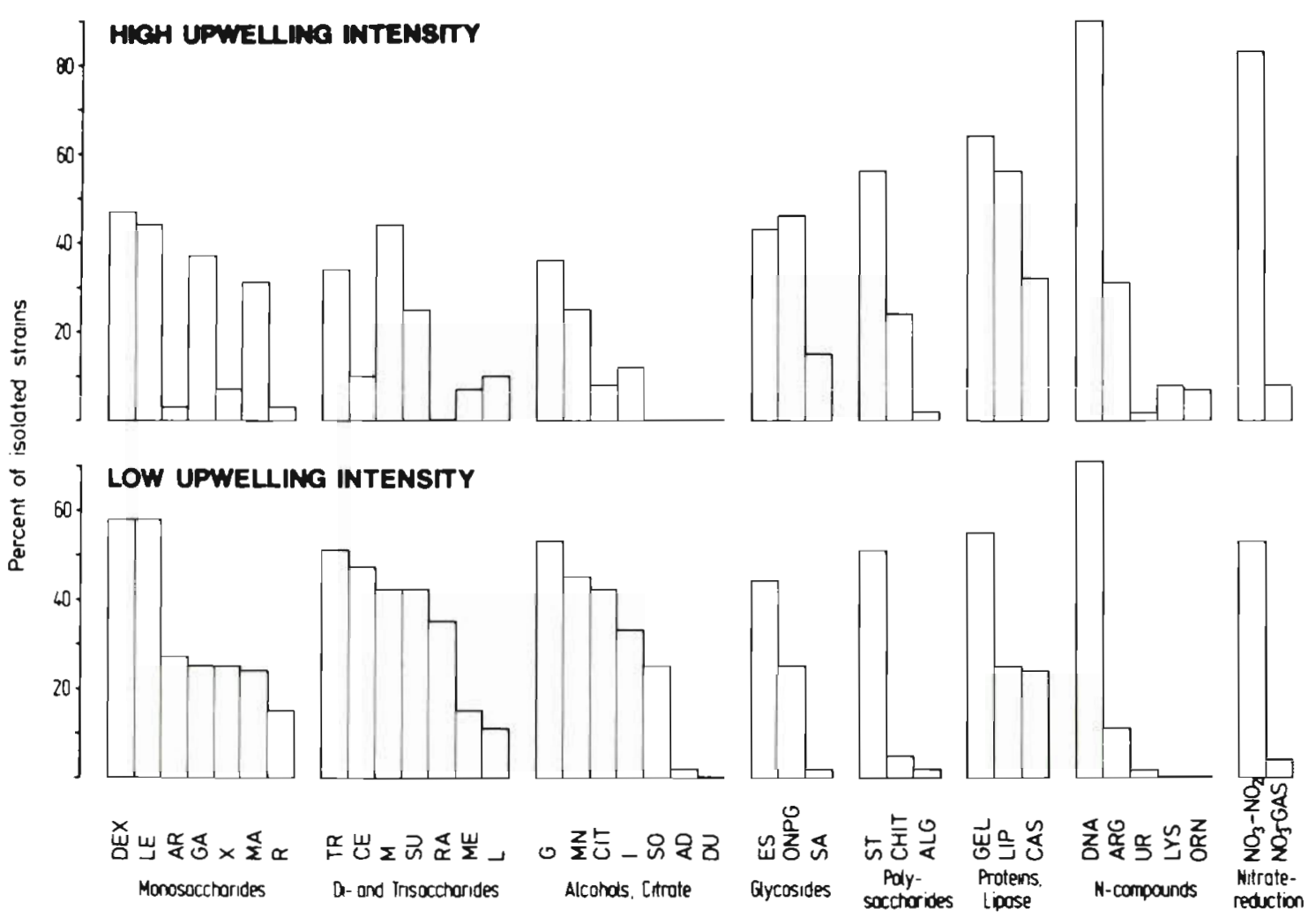

Fig. 3. Catabolic potentials of benthic bacteria from regions with different upwelling intensities (percent of isolates with positive test results) 
uniform environmental conditions in regions with low upwelling intensities, too.

The isolates were identified according to Bergey's manual of systematic bacteriology $(1984,1986)$ and to numerous original publications about the taxonomy of Alteromonas, Bacillus and Vibrio. The taxonomic characteristics of most of the strains were not in accordance with the descriptions given for any known species. The strains could therefore be identified only to genus level and represent new taxa within the respective genera. Descriptions of these taxa will be published elsewhere.

Species of the genus Bacillus were originally soil bacteria and are characterized by spore formation in adverse conditions. However, aerobic sporeformers are also common inhabitants of marine sediments (Rüger 1973, Brisou et al. 1978, Bensoussan et al. 1979, Bonde 1981). Bacillus marinus (ex Bacillus globisporus subsp. marinus Rüger \& Richter, 1979) is an obligate marine species (Rüger \& Hentzschel 1980, Rüger 1983). Some other Bacillus strains from deep-sea sediments required seawater base for growth and grew well at temperatures between 1 and $20^{\circ} \mathrm{C}$. They utilized numerous organic substrates at $4^{\circ} \mathrm{C}$ but not at $20^{\circ} \mathrm{C}$ and proved to be highly adapted to deep-sea conditions (Rüger 1988).

Bacterial spores are less abundant in marine sediments than vegetative cells (Table 2 and Rüger 1975). It is concluded that the greatest part of our isolates from $35 / 29^{\circ} \mathrm{N}$ have evolved from vegetative cells. All the

Table 3. Comparison of bacteria from the Cape Blanc area at $21^{\circ} \mathrm{N}$ isolated from spread plates incubated at $15^{\circ} \mathrm{C}$ in 1975 and $2{ }^{\circ} \mathrm{C}$ in 1982. Strs: strains

\begin{tabular}{|c|c|c|c|c|}
\hline \multirow[t]{3}{*}{ Trait } & \multicolumn{4}{|c|}{ Percent of isolated strains } \\
\hline & \multicolumn{2}{|c|}{ Incubation at $15^{\circ} \mathrm{C}$} & \multicolumn{2}{|c|}{ Incubation at $2^{\circ} \mathrm{C}$} \\
\hline & $\begin{array}{c}85-1023 \mathrm{~m} \\
\text { (83 strs) }\end{array}$ & $\begin{array}{c}1318-1745 \mathrm{~m} \\
(54 \mathrm{strs})\end{array}$ & $\begin{array}{c}100-800 \mathrm{~m} \\
(29 \mathrm{strs})\end{array}$ & $\begin{array}{c}1200-1500 \mathrm{~m} \\
\text { (30 strs) }\end{array}$ \\
\hline \multicolumn{5}{|l|}{ Taxonomy } \\
\hline Agrobacterium & 87 & 17 & 0 & 7 \\
\hline Bacillus & 2 & 74 & 0 & 0 \\
\hline Alteromonas & 0 & 0 & 59 & 36 \\
\hline Vibrio & 7 & 0 & 41 & 50 \\
\hline Various genera & 4 & 9 & 0 & 7 \\
\hline \multicolumn{5}{|l|}{ Physiology } \\
\hline Extremely psychrophilic & 0 & 0 & 4 & 23 \\
\hline Psychrophilic & 0 & 0 & 48 & 67 \\
\hline Psychrotrophic & 31 & 20 & 48 & 10 \\
\hline Mesophilic & 69 & 80 & 0 & 0 \\
\hline Growth in freshwater media & 31 & 67 & 3 & 13 \\
\hline \multicolumn{5}{|l|}{ Acid from } \\
\hline Glucose & 29 & 70 & 41 & 53 \\
\hline Arabinose & 1 & 55 & 0 & 7 \\
\hline Fructose & 8 & 69 & 38 & 50 \\
\hline Glycerol & 13 & 68 & 28 & 43 \\
\hline Lactose & 7 & 33 & 10 & 10 \\
\hline Maltose & 16 & 77 & 41 & 47 \\
\hline Mannitol & 8 & 60 & 21 & 30 \\
\hline Sucrose & 19 & 83 & 28 & 23 \\
\hline Xylose & 5 & 55 & 7 & 7 \\
\hline \multicolumn{5}{|l|}{ Utilization of } \\
\hline Urea & 5 & 39 & 0 & 3 \\
\hline Gelatin & 6 & 26 & 76 & 53 \\
\hline Casein & 7 & 26 & 34 & 30 \\
\hline Arginine & 22 & 11 & 31 & 30 \\
\hline Starch & 8 & 35 & 52 & 60 \\
\hline Tributynn (Lupase) & 41 & 52 & 62 & 50 \\
\hline Citrate & 12 & 22 & 1.0 & 7 \\
\hline Chitin & 3 & 0 & 28 & 20 \\
\hline Nitrate reduction to $\mathrm{NO}_{2}$ & 86 & 37 & 86 & 80 \\
\hline Nitrate reduction to gas & 68 & 4 & 10 & 7 \\
\hline
\end{tabular}


strains, including the bacilli, were isolated on seawater agar at $2{ }^{\circ} \mathrm{C}$ and all identification tests were performed in seawater media. Although not dependent on seawater base for growth, these strains are thought to contribute to the bacterial communities in this area.

Since every isolation procedure is highly selective, one cannot know whether we isolated members of the 'true' communities, i.e. those bacterial populations in the ecosystem which are not dormant, but metabolically active under the environmental and nutritional conditions given. During an earlier expedition to the northwest African upwelling region in 1975, we found bacterial communities different to those in 1982, but at that time we used an incubation temperature of $15^{\circ} \mathrm{C}$ for the enumeration and isolation of bacteria. Agrobacterium-like bacteria predominated in depths between 85 and $1023 \mathrm{~m}$ and members of the genus Bacillus in the depth range 1318 to $2998 \mathrm{~m}$ (Rüger 1985 and Table 3). These different results might be caused by changes in the environment during the period elapsed between the 2 expeditions or, more likely, by the selective effect of the different incubation temperatures applied.

No psychrophilic bacteria were isolated in 1975. Most of the Agrobacterium-like strains were not able to grow in freshwater media and are considered true marine bacteria, actively metabolizing at least in shallow stations, where sediment temperatures were higher than at deeper stations. At $4{ }^{\circ} \mathrm{C}$ these organisms were not able to utilize numerous carbohydrates and $\mathrm{N}$-compounds within $8 \mathrm{wk}$ of incubation, but these substrates were utilized within 2 wk at $20^{\circ} \mathrm{C}$ (unpubl.). Only a few of the Bacillus strains isolated at $15^{\circ} \mathrm{C}$ in 1975 were able to grow at $5^{\circ} \mathrm{C}$ or required seawater media for growth, indicating that these organisms exhibited only low metabolic activities in the environment or even survived in a dormant state. These results were rather surprising, because the applied incubation temperature of $15^{\circ} \mathrm{C}$ did not differ greatly from the average temperatures found in the northwest African upwelling region (Table 2, Fütterer 1983). Moreover, the greatest proportion of the strains isolated at $2^{\circ} \mathrm{C}$ was also able to grow at $15^{\circ} \mathrm{C}$ (Fig. 1; Table 3 ) and one could postulate that these organisms could also have been isolated at this higher incubation temperature.

The proportion of strains capable of utilizing various carbohydrates, sugar alcohols and citrate was relatively high among the isolates from the area of low upwelling intensity, but decreased significantly in the central upwelling area. This might be connected with the observation that bacteria with an active respiratory electron transport system are less abundant in the Cape Blanc area than in the northern regions (Tan \& Rüger 1989). Higher numbers of strains able to utilize various
$\mathrm{N}$-compounds and to reduce nitrates to nitrites, as found at $17 / 21^{\circ} \mathrm{N}$, might be due to a maximum concentration of $\mathrm{N}$-containing matter in this area of maximum upwelling intensity and a drastic decrease in the concentrations of these substrates north of it (Summerhayes 1983).

\section{CONCLUSIONS}

Any available method for studying marine bacterial communities by isolations of strains is selective in quality and quantity; the incubation temperatures applied for the isolation of bacteria are of especially great importance. In spite of these limitations, distinct benthic bacterial communitites were found in the centre of the northwest African upwelling area and a northern region low in upwelling intensity. The differences between these communities may be due the environmental and nutritional conditions in the area of investigation.

Acknowledgements. I thank Professor H. Thiel (Institut für Hydrobiologie und Fischereiwissenschaft, Hamburg) for giving me the opportunity to join the expedition and his cooperation in obtaining sediment samples, Dr T. L. Tan for helpful discussions and reading the manuscript and Christa Summa and Kirsten Fahl for very skillfull technical assistance. This research was supported by grants from the 'Deutsche Forschungsgemeinschaft' to Prof. H. Thiel and to H.-J. Rüger

\section{LITERATURE CITED}

Baross, J. A., Morita, R. Y. (1978). Microbial life at low temperatures: ecological aspects. In: Kushner, D. J. (ed.) Microbial life in extreme environments. Academic Press, London, p. 9-71

Baumann, P., Gauthier, M. J., Baumann, L. (1984). Genus Alteromonas Baumann, Baumann, Mandel and Allen 1972. In: Krieg, N. R., Holt, J. G. (eds.) Bergey's manual of systematic bacteriology, Vol. 1. Willians and Wilkins, Baltimore, p. 343-352

Bensoussan, M. (1979). Bactériologie des eaux et des sédiments profonds en Atlantique intertropical est. II. - Potentialités cataboliques des populations bactériennes hétérotrophes aérobies. In: Arnould, M., Pelet, R. (eds.) Géochimie organique des sédiments marins profonds, ORGON III, Mauritanie, Sénégal, Iles du Cap-Vert. C.N.R.S., Paris, p. 27-43

Bensoussan, M., Bianchi, A., Bianchi, M., Boudabous, A., Marty, D., Roussos, S., Lizarraga-Partida, M.-L. (1979). Bactériologie des eaux et des sédiments profonds en Atlantique intertropical est. I. - Distribution et structure des populations bactériennes. In: Arnould, M., Pelet, R. (eds.) Geochimie organique des sédiments marins profonds, ORGON III, Mauritanie, Sénégal, Iles du Cap-Vert. C.N.R.S., Paris, p. $13-25$

Bergey's manual of systematic bacteriology, Vol. 1 (1984). Krieg, N. R., Holt, J. G. (eds.) Williams and Wilkins, Baltimore

Bergey's manual of systematic bacteriology, Vol. 2 (1986). 
Sneath, P. H. A., Mair, N. S., Sharpe, M. E., Holt, J. G. (eds.) Williams and Wilkins, Baltimore

Bianchi, M. A. G., Bianchi, A. J. M. (1982). Statistical sampling of bacterial strains and its use in bacterial diversity measurement. Microb. Ecol. 8: 61-69

BöIter, M., Meyer-Reil, L. -A. (1974). Untersuchungen an Bakterienstämmen aus dem Auftriebsgebiet vor der westafrikanischen Küste: Taxonomie und Nährstoffansprüche. Botanica mar. 17: 227-248

Boje, R. Tomczak, M. (1978). Ecosystem analysis and the definition of boundaries in upwelling regions. In: Boje, $R$, Tomczak, M. (eds.) Upwelling ecosystems. Springer-Verlag, Berlin, p. 3-11

Bonde, G. J. (1981). Bacillus from marine habitats: allocation to phena established by numerical techniques. In: Berkeley, R. C. W., Goodfellow, M. (eds.) The aerobic endospore-forming bacteria: classification and identification. Academic Press, London, p. 181-215

Brisou, J., de Barjac, H., Moreau, R. (1978). Sur quelques Bacillus isolés en mer Méditerranée. Revue Cytol. Biol. vég. - Bot 1: 405-412

Fütterer, D. K. (1983). The modern upwelling record off Northwest Africa. In: Thiede, J., Suess, E. (eds.) Coastal upwelling - its sediment record. Part B: Sedimentary records of ancient coastal upwelling. Plenum Press, New York, p. $105-121$

Gray, P. A., Steward, D. J. (1980). Numerical taxonomy of some marine pseudomonads and alteromonads. J. appl. Bact. 49: 375-383

Harder, W., Veldkamp, H. (1968). Physiology of an obligately psychrophilic Pseudomonas species. J. appl. Bact. 31: $12-23$

Kölbel-Boelke, J., Tienken, B., Nehrkorn, A. (1988). Microbial communities in the saturated groundwater environment $\mathrm{I}$ : Methods of isolation and characterization of heterotrophic bacteria. Microb. Ecol. 16: 17-29

Meyer-Reil, R.-A., Rheinheimer, G. (1973). Bakteriologische Untersuchungen im Auftriebsgebiet vor der westafrikanischen Küste und im Sediment des Küstenschelfes 'Meteor' Forsch. Ergebn. D 16: 33-41

Namsaraev, B. B. (1985). Distribution of cellulose-decomposing microorganisms in bottom sediments of the Indian Ocean. Microbiology 53: 801-807 (Translated from Mikrobiologiya 53: 982-988, 1984)

Norkrans, B., Stehn, B. O. (1979). Sediment bacteria in the deep Norwegian Sea. Mar. Biol. 47: 201-209

Pfannkuche, O., Theeg, R., Thiel, H. (1983). Benthos activity, abundance and biomass under an area of low upwelling off Morocco, Northwest Africa. 'Meteor' Forsch. Ergebn D 36: 85-96

Roszak, D. B., Colwell, R. R. (1987). Survival strategies of bacteria in the natural envronment. Microbiol. Rev. 51: $365-379$

Rüger, H.-J. (1973). Zum Vorkommen aerober sporenbildender Bakterien in nordostatlantischen Tiefseesedimenten. 'Meteor' Forsch. Ergebn. D 16: 60-64

Rüger, H.-J. (1975). Bakteriensporen in marinen Sedimenten (Nordatlantik, Skagerrak, Biskaya und Auftriebsgebiet vor Nordwestafrika) - quantitative Untersuchungen. Veröff Inst. Meeresforsch. Bremerhaven 15: 227-236

Rüger, H. -J. (1981). Comparison of the API and Minitek iden-

This article was submitted to the editor tification systems with conventional methods for differentiating marine bacteria. Veröff. Inst. Meeresforsch. Bremerhaven 19: 21-34

Rüger, H.-J. (1982). Psychrophilic sediment bacteria in the upwelling area off NW-Africa. Naturwissenschaften 69 : $448-450$

Rüger, H.-J. (1983). Differentiation of Bacillus globisporus, Bacillus marinus comb. nov, Bacillus aminovorans, and Bacillus insolitus. Int. J. system. Bacteriol. 33: 157-161

Rüger, H.-J. (1985). Benthic studies of the Northwest African upwelling region: structures and catabolic potentials of mesophilic bacterial communities. Veröff. Inst. Meeresforsch. Bremerhaven 21: 97-114

Rüger, H.-J. (1986). Distribution, growth temperatures, and Gram reactions of psychrophilic sediment bacteria from tropical and subtropical regions off West-Africa. Deuxième Colloque International de Bactériologie marine - CNRS Brest, 1-5 octobre 1984. IFREMER, Actes de Colloques 3 : $97-101$

Rüger, H.-J. (1988). Substrate-dependent cold adaptations in some deep-sea sediment bacteria. Syst. appl. Microbiol 11: $90-93$

Rüger, H.-J, Hentzschel, G. (1980). Mineral salt requirements of Bacillus globisporus subsp. marinus strains. Arch. Microbiol. 126: 83-86

Summerhayes, C. P. (1983). Sedimentation of organic matter in upwelling regimes. In: Thiede, J., Suess, E. (eds.) Coastal upwelling - its sediment record. Part B: Sedimentary records of ancient coastal upwelling. Plenum Press, New York, p. 29-72

Tan, T L., Rüger, H.-J. (1989). Benthic studies of the Northwest African upwelling region: bacteria standing stock and ETS-activity, ATP-biomass and Adenylate Energy Charge. Mar. Ecol. Prog. Ser. 51: 167-176

Tejero, A. (1978). Estudio bacteriológico de la zona de afloramiento del NW de Africa (Campaña 'Atlor VII'). II. Taxonomia numérica de bacterias heterotrófas aisladas en el NW de Africa. Result. Exped. cient. Buque oceanogr 'Cornide de Saavedra' 7: 131-143

Tejero, A., Esteves, E., Vallespinós, F. (1978). Estudio bacteriológico de la zona de afloramiento del. NW de Africa (Campaña 'Atlor VII'). I. Técnicas de identificación taconómica y resultados, Result. Exped. cient. Buque oceanogr. 'Cornide de Saavedra' 7: 59-76

Thiel, H. (1981). Benthic investigations in the Northwest African upwelling area. Report on the cruises 26, 36, 44 and 53 of R.V 'Meteor' 'Meteor' Forsch. Ergebn. D 33: 1-15

Thiel, H. (1982). Zoobenthos of the Cineca area and other upwelling regions. Rapp. P.-v. Réun. Cons. int. Explor Mer 180: 323-334

Weyland, H., Rüger, H.-J., Schwarz, H. (1970). Zur Isolierung und Identifizierung mariner Bakterien. Ein Beitrag zur Standardisierung und Entwicklung adäquater Methoden. Veröf. Inst. Meeresforsch. Bremerhaven 12: 269-296

Yayanos, A. A., Dietz. A. S. (1982). Thermal inactivation of a deep-sea barophilic bacterium, isolate CNPT-3. Appl. environ. Microbiol. 43: 1481-1.489

Zimmermann, R., Bölter, M., Wolter, K. (1980). Bakteriologisch-ökologische Untersuchungen im Gebiet des westafrikanischen Küstenauftriebs. Botanica mar. 23: 179-191

Manuscript first received: April 20,1989

Revised version accepted: June 30, 1989 